\title{
COMBINED EFFECT OF LIGHTING AND HIGH AIR TEMPERATURE ON HUMAN VISUAL PERFORMANCE
}

\author{
Nazarenko V. I., Martirosova V. G., Cherednichenko I. M., \\ Tikhonova N. S., Beseda O. Y.

\section{State Institution «Kundiiev Institute of Occupational health of the National Academyof Medical Sciences of Ukraine», Kyiv}

Introduction. Preventing adverse effects of industrial factors at workplaces of office workers, engaged in intensive mental work, is one of important problems of modern occupational health. One of the factors that can positively affect a human body and promote a high level of work efficiency is comfortable levels of lighting. However unfavorable microclimatic conditions can cause a negative impact. Therefore, studying peculiarities of the combined influence of factors of the work environment on humans is important for development of preventive measures, especially concerning active introduction of energy saving LED light sources.

The purpose of the research was to study peculiarities of the combined effect of lighting and high air temperature in a laboratory experiment and develop hygienic recommendations.

Materials and methods of the research. The combined effect of the air temperature of $21{ }^{\circ} \mathrm{C}$ and $27{ }^{\circ} \mathrm{C}$ and lighting of $200 \mathrm{~lx}$ and $600 \mathrm{~lx}$ were studied in the laboratory experiment. In general lighting systems, LED light sources with the color temperature of $4000 \mathrm{~K}$ were used. Four series of studies, involving healthy male volunteers $(\mathrm{N}=8)$, aged 21-22, without any pathology in the organ of vision, were undertaken. The duration and frequency of experimental series were from 9-00 to 12-30 a. $\mathrm{m}$., in a day. The integral parameters of the functional state of specific physiological body systems were evaluated: visual performance (according to the time of execution a complex visual task) and the average body temperature.

Results. The experimental studies of the combined effect of the air temperature in the range of $21{ }^{\circ} \mathrm{C}-27^{\circ} \mathrm{C}$ and lighting of 200-600 lx indicate that these factors actively influence the functional state of the visual analyzer and the thermal state of volunteers. On the basis of the results of the studies, the regression equations were calculated on the dependence of the visual performance and the human thermal state on lighting and the high air temperature. It has been established that the optimal air temperature $\left(21^{\circ} \mathrm{C}\right)$ and lighting $(600 \mathrm{~lx})$ within the exposure time of 3.5 hours contribute to $53 \%$ improvement of the visual performance as compared to its level at the beginning of the experiment, and the most unfavorable combination of factors $\left(27^{\circ} \mathrm{C}\right.$ and $\left.200 \mathrm{~lx}\right)$ results in its decline by $45 \%$. The positive effect of lighting with the level of $600 \mathrm{~lx}$ on the thermal state of volunteers was noted only at the background of the air temperature of $21{ }^{\circ} \mathrm{C}$; at the elevated air temperature of $27{ }^{\circ} \mathrm{C}$ the effect was not recorded $(\mathrm{p}<0,05)$.

Conclusion. Based on the analysis of the regression equations on the dependence of the visual performance and the human thermal state on the levels of factors used in the experiment, it can be concluded that the increase in the levels of lighting up to 600 lux cause a positive effect on the visual performance and the thermal state of volunteers, whereas the increase in the air temperature above the sanitary norms $\left(25^{\circ} \mathrm{C}\right.$ and higher $)$ leads to signs of accumulation of heat in the body and decrease in the level of visual performance when conducting precise visual works.

The results of the research indicate the need of further scientific support in determining the effect of LED lighting on visual performance and the functional human state, taking into account the influence of other factors of the work environment for development of hygienic recommendations.

Key words: combined effect, lighting, high air temperature, visual performance

\section{Introduction}

Preventing adverse effects at workplaces of office workers, engaged in intensive mental work, is one of important problems of modern occupational health [1-5]. There are developing guidelines for improving working conditions of professional computer users, typical for modern offices in EU countries [2,3]. One of the factors that can positively affect the human body and promote the high level of work efficiency is cre- ation of comfortable levels of lighting [6, 7]. On the other hand, unfavorable microclimatic conditions, monotonous work can cause negative effects [8]. Therefore, studying the peculiarities of the combined effects of factors of the work environment at workplaces of office workers is important for development of preventive measures, especially concerning active introduction of energy saving LED sources in various fields of modern human activity $[6,11]$. The LED light 
sources are of high energy efficiency, able to emit $90-100 \%$ radiation in a visible range at low power consumption. In addition, they are durable, do not contain mercury. A. V. Aladov and others (2010) note that LED sources of light are 8-10 times more efficient than incandescent lamps and 1.5-2.5 times than fluorescent lamps [9].

It is suggested that the assessment of the impact of LED light sources by subjective sensations can be used to establish the most optimal, comfortable parameters of the light environment. So, according to J.-H. Lee et al. (2014), based on subjective assessments of the light environment, the most comfortable conditions for modern offices are lighting of 400-700 lx and the color temperature of light sources of $4200 \mathrm{~K}$ (neutral white light) [10]. According to leading ukranian and foreign experts, further research on the effect of LED light sources on the human body is needed, concerning determination of delayed effects, in particular [11-14].

The literature data does not provide evidence on identification of peculiarities of the lighting exposure with due account of the combined effect of other unfavorable factors of the work environment, based on the objective assessment of the functional state of the human visual analyzer.

The purpose of the study was to establish the peculiarities of the combined effect of lighting and the high air temperature in the laboratory experiment and to work out hygienic recommendations.

\section{Materials and methods of the research}

In the laboratory experiment, the combined effects of main factors of the work environment at workplaces of modern offices was simulated, where the temperature was in the range of $21-27^{\circ} \mathrm{C}$, and the level of lighting from 200 to 600 lux. The laboratory experiment was carried out in accordance with the methodical recommendations (MR) № 4223-86 «Mathematical planning and evaluation of the results of the combined exposure...» [15]. In the lighting system, developed by specialists of «Aeroplast Ltd» (Kyiv, Ukraine), LED light sources with the color temperature of $4000 \mathrm{~K}$ were used. Four series of the studies were carried out in various combinations of factors involving 8 healthy male volunteers, aged 21-22, without any visual disorders. Table 1 shows a matrix of planning the experiment.

The parameters of air velosity $(<0,1 \mathrm{~m} / \mathrm{s})$ and relative humidity $(40-60 \%)$ were within the limits of the optimal values, according to Ukrainian State Sanitary Norms 3.3.6.042-99 «State Sanitary Norms on Microclimate for Industrial Premises». The strain of visual work was typical for office works, according to the size of the subject of distinction $0,3-0,5 \mathrm{~mm}$, and corresponded to class 1 according to the Ukrainian Hygienic Classification of Labor (HCL) № 248 (2014). It was modeled by a proof test by the method of the Landolt rings (with torn rings).

The normative (permissible) values of factors were taken as a «basic» («zero») level for the effect of physical factors: air temperature $-24{ }^{\circ} \mathrm{C}$ (for the cold period of the year), lighting $-400 \mathrm{~lx}$. The duration of each series of the experiment was from 9-00 to 12-30 a. m. The series were repeated in a day. The functional state of specific physiological systems was assessed as a body reaction, such as by visual performance according to the time of performance of the complex visual task (TPCVT) and the average body temperature (ABT) according to MR № 5168-90 «Estimation of the thermal human state...» [16]. The assessment of the visual performance was made according to the original testobject method. The time used to fulfil a task and a number of errors when viewing the given quantity of Landolt' rings were defined [17]. According to the results of changes in physiological parameters and in accordance with MR No.4223-86 regression equations were calculated which showed the direct effect and effects of factors' interaction in their combined effect. The research was conducted in the special experimental premises with the LED lighting system and CREE

Table 1

Matrix of planning the multi-factorial experiment

\begin{tabular}{|c|c|c|c|c|}
\hline \multirow{2}{*}{$\begin{array}{c}\text { Variant of the } \\
\text { research }\end{array}$} & \multirow{2}{*}{ Code of variants } & \multicolumn{3}{|c|}{ Levels of the factors } \\
\cline { 3 - 4 } & $(0)$ & Lighting, lx & Air temperature ${ }^{\circ} \mathbf{C}$ & \multicolumn{1}{|c}{ Strain of the visual work } \\
\hline 1 & $\mathrm{~A}$ & 200 & 27 & \multirow{2}{*}{ Class. 3.1 (by Classification № 248) } \\
\hline 2 & $\mathrm{~B}$ & 600 & 21 & \\
\hline 3 & $\mathrm{AB}$ & 200 & 21 & \\
\hline 4 & & &
\end{tabular}


U-cool DC climate control system (power 3,5/3.8 kW) in automatic mode. Statistical processing of the obtained data was made with «Statistica $7 »$ program.

\section{Results}

Table 2 presents the initial values before the exposure and changes of the values of the visual perfomance in all 4 series of the laboratory experiment: $600 \mathrm{~lx}$ and $21^{\circ} \mathrm{C}, 600 \mathrm{~lx}$ and $27^{\circ} \mathrm{C}, 200 \mathrm{~lx}$ and $21^{\circ} \mathrm{C}, 600 \mathrm{~lx}$ and $21{ }^{\circ} \mathrm{C}$.

As it is clear from Table 2, at the optimum air temperature $\left(21^{\circ} \mathrm{C}\right)$ for the cold period of the year, according to the State norms 3.3.042-99 $\left(21^{\circ} \mathrm{C}-23^{\circ} \mathrm{C}\right)$, and lighting of $600 \mathrm{~lx}$ in experimental conditions, there is recorded the decrease in the time for visual performance of the complex visual task by $(34,88 \pm 5,72) \mathrm{s}$, on the average, and at the elevated air temperature $\left(27{ }^{\circ} \mathrm{C}\right)$, which exceeds the permissible level by $3{ }^{\circ} \mathrm{C}$ (for the category of works «light $\mathrm{Ib} »$ ) and the minimum level of lighting of $200 \mathrm{~lx}$, the time of performance of the complex visual task increases by $(16,0 \pm$ $4,06) \mathrm{s}(\mathrm{p}<0,05)$. Thus, the optimal levels of the air temperature and lighting contribute to the increase in the visual efficiency by $54,7 \%$, and the most unfavorable combination of factors $\left(27^{\circ} \mathrm{C}\right.$ and 200 lux $)$ leads to its decrease by $28,6 \%$ as compared with the initial value. In other combinations of factors the time for performance of the the test complex visual work was not significantly changed ( $p>0,05)$.

The number of errors during performance of the test-task for 3,5 hours in all series did not significantly change in comparison with the initial value $(p>0,05)$.

Table 3 shows changes in the integral parameters of volunteers' thermal state - the average body temperature $(\mathrm{ABT})$ of volunteers in different combinations of factors in the experiment.

As it can be seen from the data in Table 3, the greatest changes in the integral parameter of the thermal state of volunteers are recorded at the temperature of $27^{\circ} \mathrm{C}$ up to $(0,85 \pm 0,19)^{\circ} \mathrm{C}$, especially at the lowest level of lighting - $200 \mathrm{~lx}$, indicating the accumulation of heat in the human body. The influence of the temperature of $21{ }^{\circ} \mathrm{C}$ and lighting of $200 \mathrm{~lx}$, caused the loss of heat in the body - decrease in the average bidy temperature $(\mathrm{ABT})$ by $(0,54 \pm 0,07){ }^{\circ} \mathrm{C}$, however in lighting of $600 \mathrm{~lx}$ the changes were not significant $(\mathrm{p}>0,05)$, indicating the probable energy light impact on the human body, which should be taken into account when evaluating the thermal state at the background of comfortable indoor temperatures.

There was developed a matrix of changes of visual performance in the experiment in accordance with MR No.4223-86, based on the calculation of the

Changes of the visual performance in volunteers in the experiment $(X \pm m)$

\begin{tabular}{|c|c|c|c|c|c|c|c|c|}
\hline \multirow{4}{*}{ Indicator } & \multicolumn{8}{|c|}{ Combination of factors } \\
\hline & \multicolumn{2}{|c|}{$600 \mathrm{~lx}, 21^{\circ} \mathrm{C}$} & \multicolumn{2}{|c|}{$600 \mathrm{~lx}, 27^{\circ} \mathrm{C}$} & \multicolumn{2}{|c|}{$200 \mathrm{~lx}, 21^{\circ} \mathrm{C}$} & \multicolumn{2}{|c|}{$200 \mathrm{~lx}, 27^{\circ} \mathrm{C}$} \\
\hline & \multicolumn{2}{|c|}{ visual performance } & \multicolumn{2}{|c|}{ visual performance } & \multicolumn{2}{|c|}{ visual performance } & \multicolumn{2}{|c|}{ visual performance } \\
\hline & TPCVT, s & Errors, $\mathbf{N}$ & TPCVT, s & Errors, $\mathbf{N}$ & TPCVT, s & Errors, $\mathbf{N}$ & TPCVT, s & Errors, $\mathbf{N}$ \\
\hline Initial value & $63,6 \pm 3,3$ & $\begin{array}{c}1,37 \pm \\
0,62\end{array}$ & $56,1 \pm 4,9$ & $4,0 \pm 1,23$ & $\begin{array}{c}65,80 \pm \\
4,26\end{array}$ & $\begin{array}{c}4,50 \pm \\
1,24\end{array}$ & $\begin{array}{c}56,40 \pm \\
5,47\end{array}$ & $\begin{array}{c}5,37 \pm \\
1,14\end{array}$ \\
\hline $\begin{array}{l}\text { Changes at the end } \\
\text { of exposure }\end{array}$ & $\begin{array}{c}-34,88 \pm \\
5,72 *\end{array}$ & $\begin{array}{c}+1,75 \pm \\
1,39\end{array}$ & $\begin{array}{c}+7,50 \pm \\
4,27\end{array}$ & $\begin{array}{c}+0,38 \pm \\
1,12\end{array}$ & $\begin{array}{c}-6,50 \pm \\
4,53\end{array}$ & $\begin{array}{c}-1,50 \pm \\
1,83\end{array}$ & $\begin{array}{c}+16,0 \pm \\
4,06^{*}\end{array}$ & $\begin{array}{c}-2,25 \pm \\
1,47\end{array}$ \\
\hline
\end{tabular}

Note. ${ }^{*}$ The difference is significant in comparison with initial values $(p<0,05)$.

Tahle 3

Changes of the average body temperature in volunteers in different combinations of factors

\begin{tabular}{|c|c|c|c|c|}
\hline \multirow{2}{*}{ Parameter STT } & \multicolumn{4}{|c|}{ Combination of factors } \\
\cline { 2 - 5 } & $\mathbf{2 1}{ }^{\circ} \mathbf{C}, \mathbf{6 0 0} \mathbf{~ l x}$ & $\mathbf{2 7}^{\circ} \mathbf{C}, \mathbf{6 0 0} \mathbf{~ l x}$ & $\mathbf{2 1}^{\circ} \mathbf{C}, \mathbf{2 0 0} \mathbf{~ x}$ & $\mathbf{2 7}{ }^{\circ} \mathbf{C}, \mathbf{2 0 0} \mathbf{~ l x}$ \\
\cline { 2 - 5 } & \multicolumn{4}{|c|}{ Changes in the average body temperature, ${ }^{\circ} \mathbf{C}$} \\
\hline Xaverage & $-0,12$ & $+0,42^{*}$ & $-0,54^{*}$ & $+0,85^{*}$ \\
\hline$\pm \mathrm{m}$ & 0,08 & 0,09 & 0,07 & 0,19 \\
\hline
\end{tabular}

Note. ${ }^{*}$ The difference is significant in comparison with the initial value $(p<0,05)$. 
average values in each serie of the studies [15].

Table 4 shows the matrix of changes in the visual performance in the experiment (the time to solve a complex visual task) in different combinations of the air temperature and lighting in the laboratory experiment.

In the range of variations of the air temperature $6{ }^{\circ} \mathrm{C}$ and lighting $400 \mathrm{~lx}$, we receive the corresponding coefficients in the equation for changes of the visual performance in the experiment:

$$
\begin{gathered}
\Delta \mathrm{VP}=-4,48+2,71(\mathrm{~T}-24)- \\
12,5 \cdot 10^{-3}(\mathrm{I}-400)+ \\
3,9 \cdot 10^{-3}(\mathrm{~T}-24) \cdot(\mathrm{I}-400),
\end{gathered}
$$

where

$\Delta \mathrm{VP}$ - changes in the visual performance, $\mathrm{s}$,

$\mathrm{T}$ - air temperature in experimental conditions, ${ }^{\circ} \mathrm{C}$,

I - level of lighting of the working zone, lx.

The equation of the regression indicates the presence of the direct effect both of the air temperature and lighting levels on the visual performance. At the same time, the increase of the body temperature leads to the decrease of the visual performance, whereas that of lighting - on the contrary to its improvement. Also, the presence of the effect of the inter-factorial interaction between thermal influence and light is worth of attention.

Table 5 presents the matrix of changes of the average body temperature $\left({ }^{\circ} \mathrm{C}\right)$ in volunteers at various combinations of the air temperature and lighting in the laboratory experiment.

The regression equation describing the combined effect of the air temperature in the range from $21^{\circ} \mathrm{C}$ to $27{ }^{\circ} \mathrm{C}$ and levels of lighting from 200 to 600 lux is as follows:

$$
\begin{gathered}
\Delta \mathrm{ABT},{ }^{\circ} \mathrm{C}=0,15+0,07(\mathrm{~T}-24)+ \\
0,2 \cdot 10^{-3} \cdot(\mathrm{T}-24) \cdot(\mathrm{I}-400),
\end{gathered}
$$

where

$\triangle \mathrm{ABT}$ - changes in the average body temperature,

\begin{tabular}{|c|c|c|c|c|c|}
\hline \multirow{2}{*}{$\begin{array}{l}\text { Codes of factor } \\
\text { combinations }\end{array}$} & \multicolumn{5}{|c|}{ Coefficients of regression } \\
\hline & a0 & a1 & a2 & a12 & $\pm \mathbf{m}$ \\
\hline 0 & $-34,9$ & 34,9 & 34,9 & $-34,9$ & 5,72 \\
\hline A & 16,0 & 16,0 & $-16,0$ & $-16,0$ & 4,06 \\
\hline B & $-6,5$ & 6,5 & $-6,5$ & 6,5 & 4,53 \\
\hline $\mathrm{AB}$ & 7,5 & 7,5 & 7,5 & 7,5 & 4,27 \\
\hline$\Sigma$ & $-17,9$ & 64,9 & 19,9 & $-36,9$ & - \\
\hline$\Sigma / 4$ & $-4,48$ & $16,23 *$ & $4,98 *$ & $-9,22 *$ & - \\
\hline
\end{tabular}
${ }^{\circ} \mathrm{C}$,

$\mathrm{T}$ - air temperature in experimental conditions, ${ }^{\circ} \mathrm{C}$,

I - level of lighting at workplace, lx.

Matrix of changes of the visual performance in the experiment

\begin{tabular}{|c|c|c|c|c|c|}
\hline \multirow{2}{*}{$\begin{array}{l}\text { Codes of factor } \\
\text { combinations }\end{array}$} & \multicolumn{5}{|c|}{ Coefficients of regression } \\
\hline & a0 & a1 & a2 & a12 & $\pm \mathbf{m}$ \\
\hline 0 & $-0,13$ & $-0,13$ & 0,13 & 0,13 & 0,08 \\
\hline A & 0,42 & 0,42 & $-0,42$ & $-0,42$ & 0,09 \\
\hline B & $-0,54$ & 0,54 & $-0,54$ & 0,54 & 0,07 \\
\hline $\mathrm{AB}$ & 0,85 & 0,85 & 0,85 & 0,85 & 0,19 \\
\hline$\Sigma$ & 0,60 & 1,68 & 0,02 & 1,10 & - \\
\hline \multirow[t]{2}{*}{$\Sigma / 4$} & 0,15 & $0,42 *$ & 0,005 & $0,28 *$ & - \\
\hline & $\mathrm{atm}=0,26$ & \multicolumn{4}{|c|}{ - } \\
\hline
\end{tabular}

Note. *Significant coefficients of the equation $(p<0,05)$.

Matrix of changes in the average body temperature at various combinations of the air temperature and lighting in the experiment 
As it is seen from the regression equation 2 , in addition to the direct effect of the air temperature on the average body temperature, there is also an element of the inter-factorial interaction between the thermal influence and lighting, indicating the importance of the energy effect of light.

Thus, as it is shown in experimental studies with participation of specially selected young volunteersemetropes, aged 20-21, males ( $N=8$ ), levels of lighting and air temperature can affect the indicators of the visual performance and the thermal state of the human body in conditions of the laboratory experiment. At the same time, the regression equation shows the presence of the direct influence both the air temperature and lighting on the visual efficiency, and availability of the effects of the inter-factorial interaction, indicating the complex functional relationship between the visual analyzer and the system of thermoregulation in man, which requires further studying. The increase of the air temperature up to $27^{\circ} \mathrm{C}$ results in the decrease of the visual performance, whereas that of lighting up to 600 lux, on the contrary, to its improvement.

Also, the availability of effects of the inter-factorial interaction between thermal influence and lighting should be taken into account when assessing the visual performance and the thermal state at the background of comfortable and high indoor air temperatures.

On the basis of laboratory and work-related reseaches of the functional state of workers, the authors of the study propose hygienic recommendations for improving working conditions and futher introduction of LED lighting at workplaces: for offices - the level of lighting within 400-600 lx at the color temperature of energysaving sources of LED lighting $4000 \mathrm{~K}$ (neutral light), the air temperature - at the level of $21-24{ }^{\circ} \mathrm{C}$ with optimal parameters of relative humidity $(40-60 \%)$ and air velosity (no more than $0,1 \mathrm{~m} / \mathrm{s}$ ). Keeping to these requirements will improve the level of the visual performance and the thermal state of office workers, contribute to the premature prevention of fatigue in employees at workplaces.

\section{References}

1. Smith A., McNamara R. and Wellens B. (2004), Combined effects of occupational health hazards, Research report № 287, HSE Books.

2. Guidelines for using Computers. Preventing and managing discomfort, pain and injury (2013), ACC Publication: URL: http://www.acc.co.nz/ PRD_EXT_ CSMP/groups/external.../wpc090196.pdf (Accessed 05.07.2017).

\section{Conclusions}

1. The experimental studies of the combined effect of the air temperatures in the range of $21-27^{\circ} \mathrm{C}$ and LED lighting of 200-600 lx in the system of the general lighting at the background of the intense visual work suggest that these factors affect the functional state of the visual analyzer and the thermal state of volunteers. In this, the optimal air temperature $\left(21^{\circ} \mathrm{C}\right)$ and lighting $(600 \mathrm{~lx})$ contribute to the increase of the visual efficiency by $54,7 \%$, and the most unfavorable combination of factors $\left(27^{\circ} \mathrm{C}\right.$ and $200 \mathrm{~lx}$ ) leads to its decrease by $28,6 \%$. At the air temperature $21{ }^{\circ} \mathrm{C}$ and lighting $200 \mathrm{~lx}$, the visual performance indicators within the experiment was not changed $(\mathrm{p}>0,05)$.

2 . On the basis of regression equations on the dependence of the integral parameters of the thermal state and the visual performance of a man in the laboratory experiment it can be concluded that the increase in the levels of lighting up to 600 lux cause a positive effect on the visual performance and thermal state of volunteers, however the increase in the air temperature leads to accumulation of heat in the body and to decrease of the visual efficiency. The noticeable effect of lighting of $600 \mathrm{~lx}$ on the thermal state of volunteers was recorded only at the background of optimal air temperatures $21^{\circ} \mathrm{C}$; at the high temperature of $27{ }^{\circ} \mathrm{C}$ the effect was not detected $(\mathrm{p}<0,05)$.

3 . The results of the studies on modelling working conditions in modern office premises indicate the need to implement appropriate engineering and technical measures for creating the comfortable light environment that will promote the visual performance of an individual, normalization of microclimatic conditions, as well as further scientific support in terms of determining the effects of LED lighting on the functional state of employees.

3. Office ergonomics (2013), The European Agency for Safety and Health at Work, URL: https://osha.europa. eu/en (Accessed 05.07.2017).

4. Vlasova E. M., Zaitseva N. V. and Malyutina N. N. (2011), "Peculiarities of the vegetative status of individuals working with computer technology», Meditsina truda $i$ prom. ekologia, 2, 38-42.

5. Chernyuk V. I., Nazarenko V. I., Apykhtin K. O. Chui T. S., Kudievsky Ya. V. (2012). "Physiological and 
hygienic evaluation of physical factors and intensity at work places of flight operators and engineering staff in air traffic management in Ukraine», Ukrainian Journal of Occupational Health, 1 (29), 26-34.

6. Martirosova V. G., Nazarenko V. I., Dobrovolsky A. N. and Tereshchenko P. S. (2013), "Ethical issues in the introduction of new LED light sources in the work environment", Vth National Congress on Bioethics, Kiev, Ukraine, 23-25 September, 99.

7. Gornicka G. (2007), «Effect of lighting level and colour temperature on perfomance and visual comforn during the day", $18^{\text {th }}$ NSWO najaarssymposium: Proceedings of $18^{\text {th }}$ NSWO Symp., 2 Nov. 2007, Amsterdam, 53-57.

8. Tint P., Traumann A., Tuulik-Leisi V.-R. and Tuulik V. (2012), "Computer users health risks caused by the simultaneous influence of inadequate indoor climate and monotonous work", Agronomy Research biosystem engineering, 1, 261-268.

9. Aladov A. V. and Zakgeim A. L. (2012), "About a biological equivalent of radiation from LED and traditional light sources with the color temperature of 1800-100 00 K", Svetotekhnika, 3, 7-9.

10. Lee J. L, Moon J. W. and Kim S. (2014), "Analysis of occupants visual perception to refine indoor lighting environment for office tasks», Energies, 7, 4116-4139. https://doi.org/10.3390/en7074116.

11. Kozhushko G. M. and Dugnist L. V. (2015), "Specific requirements to LED lights", Naukovyi visnyk Poltavskogo universytetu ekonomiku i torgivli, 1 (73), 42-49.

12. Teksheva L. M. (2011), "Experiment: influence on the psychophysical indicators of a person. Comparison of fluorescent and LED lamps», CROM Electronics, URL: http://http://www.vsvete.com/articles/ss/vlijanie-naglaza/. (Accessed 05.07.2017).

13. Martirosova V. G., Nazarenko V. I. Sorokin V. M. and Galinsky A. D. (2011), "Investigation of the effect of radiation from LED light sources on some basic physiological systems of the human body", Svitlo luks, 2, 42-47.

14. Martirosova V. G., Nazarenko V. I., Sorokin V. M., Galinsky A. D. (2011), "Physiological and hygienic evaluation of radiation of light emitted diode sources of light", Ukrainian Journal of Occupational Health, 2, 27-35.

15. Assessment of the human thermal state for substantiation of the hygienic requirements to microclimate at workplaces and measures to prevent cooling and overheating (1990), Methodical recommendation No. 5168-90, approved by the Order of the Ministry ofHealth No. 5168-90 of 05.03.1990, Ministerstvo zdravookhranenia, Moscow, Russia.

16. Mathematical planning and evaluation of the results of the study of the combined effects of noise, vibration and microclimate in the work environment. (1986), Methodical recommendations № 4223-86, approved by the Order of the Ministry of Health No. 4223-86 of 10.12.1986, Ministerstvo zdravookhranenia, Moscow, USSR.

17. Methods for determining indicators of visual performance (1985), Methodical recommendations No. 4052-85, approved by the Order of the Ministry of Health № 4052-85 of 12.12.1985, Ministerstvo zdravookhranenia, Moscow, USSR.

\title{
Назаренко В. І., Мартіросова В. Г., Чередніченіко І. М., Тихонова Н. С., Беседа О. Ю. КОМБІНОВАНИЙ ВПАИВ ОСВІТАЕНОСТІ ТА ПІАВИШЕНОї ТЕМПЕРАТУРИ ПОВITРЯ

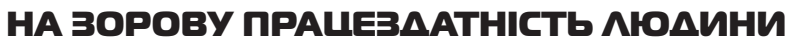

\author{
Аержавна установа «Інститут медицини праші імені Ю. І. КунАієва Нашіональної акацемії медичних наук \\ України", м. Київ
}

Bcmyn. Профілактика несприятливого впливу факторів виробничого середовища на робочих місцях офісних працівників, що займаються інтенсивною розумовою працею, є однією з важливих проблем сучасної гігієни праці. Одним з факторів, що може позитивно впливати на організм людини та підтримувати високий рівень працездатності, є створення комфортних рівнів освітленості. 3 іншої сторони, негативний вплив мають несприятливі мікрокліматичні умови. Отже, вивчення особливостей комбінованого впливу факторів виробничого середовища на організм людини є важливим для розробки профілактичних рекомендацій, особливо, за активного впровадження енергозберігаючих світлодіодних джерел світла.

Мета дослідження - встановлення особливостей комбінованого впливу освітленості та підвищеної температури повітря в лабораторному експерименті та надання гігієнічних рекомендацій.

Матеріали та методи дослідження. У лабораторному експерименті проведено дослідження комбінованої дії температури повітря $21{ }^{\circ} \mathrm{C}$ та $27^{\circ} \mathrm{C}$ і освітленості 200 лк та 600 лк, у різних поєднаннях. У системах загального освітлення використані світлодіодні джерела світла з колірною температурою 4000 К. Проведено 4 серії досліджень за участю здорових волонтерів чоловічої статі ( $\mathrm{N}=8)$ віком 21-22 років, що мали орган зору без патології. Тривалість і періодичність проведення серій експерименту - з 9-00 до 12-30 год, через одну добу. Оцінювали показники функціонального стану специфічних фізіологічних систем організму: зорову працездатність (за часом виконання складної зорової задачі) і середню температуру тіла. 
Результати. Експериментальні дослідження комбінованої дії температури повітря в діапазоні $21-27^{\circ} \mathrm{C}$ і освітленості 200-600 лк свідчать, що ці фактори активно впливають на функціональний стан зорового аналізатора та тепловий стан волонтерів. На підставі проведених досліджень були розраховані рівняння регресії щодо залежності зорової працездатності та теплового стану людини від освітленості та підвищеної температури повітря. Встановлено, що оптимальні рівні температури повітря $\left(21^{\circ} \mathrm{C}\right)$ та освітленості (600 лк) протягом експозиції 3,5 год сприяють підвищенню зорової працездатності на $53 \%$ порівняно з ії рівнем на початку експерименту, а найнесприятливіша комбінація факторів $\left(27^{\circ} \mathrm{C}\right.$ і 200 лк) призводить до ії зниження на $45 \%$. Позитивний вплив освітленості з рівнем 600 лк на тепловий стан волонтерів відмічається тільки на фоні температури повітря $21{ }^{\circ} \mathrm{C}$, на фоні підвищеної температури повітря $27^{\circ} \mathrm{C}$ цей ефект не виявляється (p $\left.<0,05\right)$.

Висновки. На підставі аналізування рівнянь регресії щодо залежності зорової працездатності та теплового стану людини від рівнів факторів, які діяли в експерименті, можна зробити висновок, що збільшення рівнів освітленості до 600 лк має позитивний вплив на зорову працездатність і тепловий стан волонтерів, але підвищення температури повітря вище санітарних норм $\left(25^{\circ} \mathrm{C}\right.$ і вище) призводить до ознак накопичення тепла в організмі та зменшення рівня зорової працездатності в разі виконання точних зорових робіт. Результати досліджень свідчать про необхідність подальшого наукового супроводу з точки зору встановлення ефектів впливу світлодіодного освітлення на працездатність та функціональний стан організму людини з урахуванням впливу інших факторів виробничого середовища та розробки профілактичних рекомендацій.

Ключові слова: комбінований вплив, освітленість, підвищена температура повітря, зорова працездатність, тепловий стан людини

\section{Назаренко В. И., Мартиросова В. Г., Чередниченко И. Н., Тихонова Н. С., Беседа О. Ю. КОМБИНИРОВАННОЕ АЕЙСТВИЕ ОСВЕШЕННОСТИ И ПОВЫШЕННОЙ ТЕМПЕРАТУРЫ ВОЗАУХА НА ЗРИТЕАЬНУЮ РАБОТОСПОСОБНОСТЬ ЧЕЛОВЕКА}

Государственное учрежАение «Институт медишины труда имени Ю. И. Кундиева Национальной академии медицинских наук Украины", г. Киев

Вступление. Профилактика неблагоприятного воздействия факторов производственной среды на рабочих местах офисных работников, занимающихся интенсивной умственной работой, является одной из важных проблем современной гигиены труда. Одним из факторов, который может положительно влиять на организм человека и поддерживать высокий уровень работоспособности, является создание комфортных уровней освещенности. С другой стороны, негативное влияние оказывают неблагоприятные микроклиматические условия. Поэтому, изучение особенностей комбинированного воздействия факторов производственной среды на организм человека является важным для разработки профилактических рекомендаций, особенно, при активном внедрении энергосберегающих светодиодных источников света.

Цель исследования - установление особенностей комбинированного воздействия освещенности и повышенной температуры воздуха в лабораторном эксперименте и предоставление гигиенических рекомендаций.

Материалы и методы исследования. В лабораторном эксперименте проведено исследование комбинированного действия температуры воздуха $21^{\circ} \mathrm{C}$ и $27^{\circ} \mathrm{C}$ и освещенности 200 лк и 600 лк, в различных сочетаниях. В системах общего освещения использованы светодиодные источники света с цветовой температурой $4000 \mathrm{~K}$. Всего проведено 4 серии исследований с участием здоровых добровольцев мужского пола $(\mathrm{N}=8)$ в возрасте 21-22 года, имевшие орган зрения без патологии. Продолжительность и периодичность проведения серий эксперимента - с 9-00 до 12-30 ч, через одни сутки. Оценивали интегральные показатели функционального состояния специфических систем организма: зрительную работоспособность (по времени выполнения сложной зрительной задачи) и среднюю температуру тела.

Результаты. Экспериментальные исследования комбинированного действия температуры воздуха в диапазоне 21-27 ${ }^{\circ} \mathrm{C}$ и освещенности 200-600 лк свидетельствуют, что эти факторы активно влияют на функциональное состояние зрительного анализатора и тепловое состояние волонтеров. На основании проведенных исследований были рассчитаны уравнения регрессии по зависимости зрительной работоспособности и теплового состояния человека от освещенности и повышенной температуры воздуха. Установлено, что оптимальные уровни температуры воздуха $\left(21^{\circ} \mathrm{C}\right)$ и освещенности $(600$ лк) в течение экспозиции 3,5 ч способствуют повышению зрительной работоспособности на $53 \%$ по сравнению с ее уровнем в начале эксперимента, а наиболее неблагоприятная комбинация факторов $\left(27^{\circ} \mathrm{C}\right.$ и 200 лк) приводит к ее снижению на $45 \%$. Положительное влияние освещенности с уровнем 600 лк на тепловое состояние волонтеров отмечается только на фоне температуры воздуха $21^{\circ} \mathrm{C}$, на фоне повышенной температуры воздуха $27^{\circ} \mathrm{C}$ этот эффект не проявляется $(\mathrm{p}<0,05)$.

Bыводы. На основании анализа уравнений регрессии по зависимости зрительной работоспособности и теплового состояния человека от уровней факторов, которые действовали в эксперименте, можно сделать вывод, что увеличение 
ISSN 2223-6775, Ukrainian Journal of Occupational Health, 2019, 15 (2), 102-109

уровней освещенности до 600 лк оказывает положительное влияние на зрительную работоспособность и тепловое состояние волонтеров, но повышение температуры воздуха выше санитарных норм $\left(25^{\circ} \mathrm{C}\right.$ и выше) приводит к признакам накопления тепла в организме и уменьшению уровня зрительной работоспособности при выполнении точных зрительных работ. Результаты исследований свидетельствуют о необходимости дальнейшего научного сопровождения с точки зрения установления эффектов воздействия светодиодного освещения на работоспособность и функциональное состояние организма человека с учетом влияния других факторов производственной среды и разработки профилактических рекомендаций.

Ключевые слова: комбинированное воздействие, освещенность, повышенная температура воздуха, зрительная работоспособность, тепловое состояние человека

ORCID ID співавторів та їхній вклад у підготовку та написання статті:

Назаренко B. I. (ORCIDID0000-0002-5238-4312) - огляд літератури, постановка мети дослідження, планування експериментальних досліджень та аналіз результатів, формулювання висновків;

Мартіросова В. Г. - дослідження зорової працездатності волонтерів;

Чередніченко I. M. (ORCIDID0000-0001-6654-1334) - дослідження теплового стану волонтерів, гігієнічна оцінка фізичних факторів і напруженості праці в експерименті;

Тихонова Н. С. (ORCIDID0000-0001-5856-9919) - контроль параметрів світлового середовища в експерименті; Беседа О. Ю. - контроль параметрів мікроклімату в експерименті.

Інформація щодо джерел фінансування дослідження: наукові дослідження проведені в рамках виконання науководослідної роботи «Обгрунтувати гігієнічні рекомендації щодо покращення умов праці та світлового середовища при застосуванні світлодіодних джерел світла в офісних приміщеннях (експериментальні дослідження)», код Держреєстрації № 0116U000502.

Надійшла: 11 березня 2019 р.

Прийнята до друку: 15 квітня 2019 р.

Контактна особа: Назаренко Василь Іванович, доктор біологічних наук, лабораторія по вивченню і нормуванню фізичних факторів виробничого середовища, ДУ «Інститут медицини праці імені Ю. І. Кундієва НАМН України», буд. 75, вул. Саксаганського, м. Київ, 01033. Тел.: + 380442891512.

Електронна пошта: vinazar@ukr.net 